\title{
PENGARUH KECERDASAN INTELEKTUAL, KECERDASAN EMOSIONAL, KECERDASAN SPIRITUAL, DAN PERILAKU BELAJAR TERHADAP PEMAHAMAN AKUNTANSI MAHASISWA FAKULTAS EKONOMI DAN BISNIS UNIVERSITAS SAM RATULANGI MANADO
}

\author{
Inriawati Parauba \\ (Email : zlaracroft@yahoo.co.id)
}

\begin{abstract}
Globalization is definitely demanding of the human resources that have the skills in every fields of works so that they can be compete in the business world. In order to deal with this globalization, it needs the skills that absolutely to be reached by continuous study process, which one of them is the accounting skill that's very needed in the economy nowadays. In order to face this competition, education world especially accounting demanded to produce the high quality output or the graduates and ready to compete in the jobs world. This research aimed to prove the influence of intelligence quotient, emotional quotient, spiritual quotient, and study behavior towards understanding of accounting of the student of Economic and Business Faculty, Sam Ratulangi University. The analysis method is linier double regression. The result gives the conclusion that is the intelligence quotient, emotional quotient, spiritual quotient, and the study behavior simultaneously have influence towards understanding of accounting of the students of Economic and Bussines Faculty, Sam Ratulangi University, while partially, intelligence quotient, emotional quotient, spiritual quotient, and study behavior significantly have not the influence towards understanding of accounting of the student of Economic and Bussines Faculty, Sam Ratulangi University Manado.
\end{abstract}

Key Words: The understanding of Accounting Students, Intelligence Quotient, Emotional Quotient, Spiritual Quotient, and the Study Behaviour.

\section{PENDAHULUAN}

\section{Latar Belakang}

Sumber daya manusia (SDM) merupakan salah satu faktor yang menentukan dalam reformasi ekonomi, yaitu terkait dengan usaha bagaimana untuk menciptakan SDM yang berkualitas dan memiliki keterampilan serta berdaya saing tinggi dalam persaingan global. Dalam kaitannya tersebut, setidaknya ada dua hal penting mengenai kondisi SDM Indonesia, yaitu adanya ketimpangan antara jumlah kesempatan kerja dan angkatan kerja, serta tingkat pendidikan angkatan kerja yang masih relatif rendah. Masalah daya saing dalam pasar dunia yang semakin terbuka merupakan tantangan yang berat. Tanpa dibekali dengan kemampuan kompetitif yang tinggi mustahil suatu negara mampu bersaing dan menembus pasar internasional. Pada era reformasi saat ini alokasi SDM belum mampu mengoreksi kecenderungan konsentrasi ekonomi yang telah tercipta sejak pemerintahan masa lalu.Sementara dilain pihak Indonesia masih kekurangan berbagai keahlian untuk mengisi kebutuhan global. Oleh sebab itu perlu adanya peningkatan kualitas sumber daya manusia, yaitu dengan meningkatkan mutu pendidikan nasional pada umumnya dan meningkatkan prestasi akademik atau keahlian dalam berbagai bidang ilmu seperti keahlian di bidang ilmu akuntansi.

Pendidikan akuntansi khususnya pendidikan tinggi akuntansi yang diselenggarakan di perguruan tinggi ditujukan untuk mendidik mahasiswa agar dapat bekerja sebagai seorang 
akuntan profesional yang memiliki pengetahuan dibidang Akuntansi Keuangan, Akuntansi Manajemen, Sistem Informasi Akuntansi, Auditing, dan Akuntansi Sektor Publik, serta ilmuilmu pengetahuan yang relevan dengan bidang akuntansi. Kecerdasan intelektual (IQ) memegang peranan penting dalam dunia pendidikan apalagi paradigma pendidikan memfokuskan pada kerangka berpikir cognitive holistic, dimana proses dan pelaksanaan pendidikan lebih mengutamakan pada perkembangan intelektual dan pemikiran rasional. Di sisi lain juga, yang perlu dipertimbangkan adalah adanya kecerdasan spiritual atau yang dikenal dengan Spiritual Quotient (SQ). Kurangnya kecerdasan spiritual seseorang akan berakibat pada kurang termotivasinya seorang mahasiwa untuk belajar, dan sulit untuk berkonsentrasi, sehingga mahasiswa akan sulit untuk memahami suatu matakuliah. Kecerdasan intelektual memegang peranan penting bagi mahasiswa dalam memahami akuntansi, namun hal ini tidak akan berjalan dengan baik bila tidak diimbangi dengan kemampuan untuk mengelola emosi (EQ) sendiri ketika dihadapkan pada permasalahan, mahasiswa yang bersangkutan akan cepat frustasi.

Penelitian ini dilakukan pada mahasiswa angkatan tahun 2009 jurusan Akuntansi Fakultas Ekonomi dan Bisnis, Universitas Sam Ratulangi yang ada di Manado. Alasan pemilihan jurusan akuntansi angkatan tahun 2009 dalam penelitian ini adalah karena dianggap sudah menerima manfaat dari proses pembelajaran akuntansi, dan juga karena pada saat dilakukan penelitian yaitu pada tahun 2013 sebagian besar sementara dalam proses penyelesaian studi.

\section{Tujuan Penelitian}

Tujuan dari penelitian ini adalah sebagai berikut.

1. Untuk menganalisis pengaruh kecerdasan intelektual terhadap pemahaman akuntansi mahasiswa

2. Untuk menganalisis pengaruh kecerdasan emosional terhadap pemahaman akuntansi mahasiswa

3. Untuk menganalisis kecerdasan pengaruh kecerdasan spiritual terhadap pemahaman akuntansi mahasiswa.

4. Untuk menganalisis pengaruh perilkau belajar terhadap pemahaman akuntansi mahasiswa.

\section{TINJAUAN PUSTAKA}

\section{Akuntansi Perilaku}

Ruang lingkup akuntansi keperilakuan meliputi:

1 Mempelajari pengaruh antara perilaku manusia terhadap konstruksi, bangunan, dan penggunaan sistem informasi yang diterapkan dalam perusahaan dan organisasi, yang berarti bagaimana sikap dan gaya kepemimpinan manajemen mempengaruhi sifat pengendalian akuntansi dan desain organisasi; apakah desain sistem pengendalian akuntansi bisa diterapkan secara universal atau tidak.

2 Mempelajari pengaruh sistem informasi akuntansi terhadap perilaku manusia, yang berarti bagaimana sistem akuntansi mempengaruhi kinerja, motivasi, produktivitas, pengambilan keputusan, kepuasan kerja dan kerja sama.

Metode untuk menjelaskan dan memprediksi perilaku manusia dan strategi untuk mengubahnya, yang berarti bagaimana sistem akuntansi dapat dipergunakan untuk mempengaruhi perilaku, dan bagaimana mengatasi resistensi itu. Disini muncul istilah freezing (membekukan) dan unfreezing (mencairkan). Contohnya perubahan sistem. Perubahan sistem bukanlah sesuatu yang mudah, tetapi perlu upaya untuk sampai pada aplikasi sistem itu sendiri karena bisa jadi ada resistensi di situ. (Suartana, 2010:1-3). 


\section{Kecerdasan Intelektual}

Bhinet dan Theodore dalam Effendi dan Praja (2012) mendefinisikan intelegensi sebagai suatu kemampuan yang terdiri dari tiga aspek, yaitu:

1. Direction; kemampuan untuk memusatkan kepada suatu masalah yang harus dipecahkan,

2. Adaptation; kemampuan untuk mengadakan adaptasi terhadap masalah yang dihadapinya atau fleksibel di dalam menghadapi masalah, dan

criticsm; kemampuan untuk mengadakan kritik, baik terhadap masalah yang dihadapi maupun terhadap dirinya sendiri. Adapun ahli yang lain yaitu Thorndike dalam Effendi dan Praja (2012) mengemukakan bahwa "intelegensi adalah kemampuan individu untuk memberikan respon yang tepat (baik) terhadap stimulus yang diterimanya".

\section{Kecerdasan Emosional}

Komponen kecerdasan emosional menurut Goleman, terdapat tujuh elemen yang membentuk kecerdasan emosional seseorang, dalam David dan Richard (2007) yang dikutip oleh Napitulu (2009), yaitu sebagai berikut.

1. Kesadaran diri; yaitu kesadaran terhadap perasaan sendiri dan kemampuan untuk mengenali dan mengelola perasaan itu.

2. Elastisitas emotional; yaitu kemampuan untuk berkinerja secara baik dan konsisten di berbagai situasi dan tekanan.

3. Motivasi; yaitu dorongan dan energi yang ada untuk mencapai hasil, meyeimbangkan tujuan jangka pendek dan jangka panjang, dan mengupayakan cita-cita walaupun menghadapi aneka tantangan dan penolakan.

4. Sensitivitas antar pribadi; yaitu kemampuan untuk merasakan kebutuhan dan perasaan orang lain dan untuk menggunakan kemampuan itu secara efektif dalam berinteraksi, dan dalam mengambil keputusan yang mempengaruhi mereka.

5. Pengaruh; yaitukemampuan untuk membujuk orang lain agar dapat mengubah sudut pandang mereka terhadap suatu masalah, persoalan, atau keputusan.

6. Tanggap; yaitukemampuan untuk menggunakan wawasan dan interaksi untuk sampai pada, dan menerapkan keputusan saat dihadapkan dengan informasi yang ambigu atau tidak lengkap.

7. Tanggungjawab dan integritas; yaitu kemampuan untuk menunjukkan komitmen terhadap suatu tindakan saat menghadapi tantangan, dan untuk bertindak secara konsisten dan sesuai dengan persyaratan etika yang dipahami.

\section{Kecerdasan Spiritual}

Berikut ini adalah beberapa pendapat tentang kecerdasan spiritual menurut para ahli dalam Zohar dan Marshall (2001) dan Agustian (2001) yang dikutip oleh Rachmi (2010) yaitu sebagai berikut.

1. Sinetar (2000)

Sinetar (2000) mendefinisikan kecerdasan spiritual sebagai pikiran yang mendapat inspirasi, dorongan, efektivitas yang terinspirasi, dan penghayatan ketuhanan yang semua manusia menjadi bagian di dalamnya.

2. Khalil A. Khavari (2000)

Khavari (2000) mendefinisikan kecerdasan spiritual sebagai dimensi non-material atau jiwa manusia.Lebih lanjut dijelaskan oleh Khavari (2000), kecerdasan spiritual sebagai 
intan yang belum terasah dan dimiliki oleh setiap insan.Manusia harus mengenali seperti adanya lalu menggosoknya sehingga mengkilap dengan tekad yang besar, menggunakannya menuju kearifan, dan untuk mencapai kebahagiaan yang abadi.

3. Zohar dan Marshall (2001)

Zohar dan Marshall (2001) mendefinisikan kecerdasan spiritual sebagai kemampuan internal bawaan otak dan jiwa manusia yang sumber terdalamnya adalah inti alam semesta sendiri, yang memungkinkan otak untuk menemukan dan menggunakan makna dalam memecahkan persoalan.

4. Ary Ginanjar Agustian (2001)

Agustian (2001) mendefinisikan kecerdasan spiritual sebagai kemampuan untuk memberi makna ibadah terhadap setiap perilaku dan kegiatan melalui langkah-langkah dan pemikiran yang bersifat fitrah, menuju manusia yang seutuhnya dan memiliki pola pemikiran yang integralistik, serta berprinsip hanya karena Allah.

\section{Perilaku Belajar}

Mahmud dalam Subini et al. (2012) mendefinisikan belajar adalah suatu perubahan dalam diri seseorang yang terjadi karena pengalaman. "Belajar adalah melakukan sesuatu yang dilakukan sebelum ia belajar atau bila kelakuannya berubah sehingga lain caranya menghadapi sesuatu situasi daripada sebelum itu," dikemukakan oleh Hilgard dalam Subini et al. (2012). Ahmadi (1993) yang dikutip oleh Hanifah dan Abdullah (2001) lebih jauh mengatakan bahwa belajar adalah suatu perubahan dalam diri manusia, sehingga apabila setelah belajar maka dapat dikatakan bahwa dalam dirinya telah berlangsung proses belajar.

Subini et al. (2012) menjelaskan faktor-faktor yang mempengaruhi proses belajar, yaitu sebagai berikut.

1. Faktor internal; yaitu faktor yang ada dalam diri individu yang sedang melakukan belajar. Faktor intenal meliputi faktor fisiologis dan psikologis. Faktor fisiologis meliputi kesehatan dan cacat tubuh, sedangkan faktor psikologis meliputi inteligensi, bakat minat, kematangan, motif, kelelahan, dan perhatian.

2. Faktor eksternal; adalah faktor yang dipengaruhi oleh kondisi lingkungan disekitar anak, yang meliputi antara lain yaitu sebagai berikut.

a. Faktor keluarga; dimana dalam lingkungan keluarga kecerdasan dipengaruhi oleh cara mendidik anak, hubungan antar anggota keluarga, suasana rumah, keadaan ekonomi keluarga, pengertian orang tua, dan latar belakang kebudayaan.

b. Faktor sekolah; yang mempengaruhi kesulitan belajar antara lain adalah guru atau dosen, metode mengajar, fasilitas, kurikulum sekolah, hubungan guru atau dosen dengan anak, relasi antar anak, disiplin sekolah, pelajaran dan waktu, standar pelajaran, kebijakan penilaian, keadaan gedung, dan tugas rumah.

c. Faktor masyarakat; yang mempengaruhi hasil belajar antara lain adalah kegiatan anak dalam masyarakat, teman bergaul, dan bentuk kehidupan dalam masyarakat.

\section{Tingkat Pemahaman Akuntansi}

Dalam Kamus Besar Bahasa Indonesia, "paham" memiliki arti pandai atau mengerti benar, sedangkan pemahaman adalah proses, cara, perbuatan memahami atau memahamkan. Ini berarti bahwa orang yang memiliki pemahaman akuntansi adalah orang yang pandai dan mengerti benar akuntansi. Dalam hal ini, pemahaman akuntansi akan diukur dengan menggunakan nilai matakuliah akuntansi yaitu Pengantar Akuntansi 1, Pengantar Akuntansi 2, Akuntansi Menengah 1, Akuntansi Menengah 2, Akuntansi Keuangan Lanjutan 1, Akuntansi 
Keuangan Lanjutan 2, Auditing 1, Auditing 2, dan Teori Akuntansi. Matakuliah tersebut merupakan matakuliah yang di dalamnya terdapat unsur-unsur yang menggambarkan akuntansi secara umum.

\section{Penelitian Terdahulu}

Dwijayanti (2009) mencoba meneliti tentang pengaruh kecerdasan emosionl, kecerdasan intelektual, kecerdasan spiritual dan kecerdasan sosial terhadap pemahaman akuntansi.Metode yang digunakan dalam pegambilan data adalah metode convenience sampling, dengan kriteria mahasiswa program strata satu (S1) yang sedang menyusun skripsi karena dianggap telah menerima manfaat dari pengajaran akuntansi.Hasil penelitian menunjukkan bahwa kecerdasan emosional dan kecerdasan sosial berpengaruh terhadap pemahaman akuntansi, sedangkan kecerdasan intelektual dan kecerdasan spiritual tidak berpengaruh terhadap pemahaman akuntansi.

Napitupulu (2009) menguji pengaruh kecerdasan intelektual dan kecerdasan emosional terhadap tingkat pemahaman pelajaran akuntansi. Data diperoleh dengan metode survei dengan menyebarkan kuisioner kepada siswa-siswa kelas tiga Sekolah Menengah Kejuruan Bisnis dan Manajemen untuk jurusan Akuntansi. Hasil analisis menunjukkan bahwa data sudah terdistribusi dengan normal, tidak terjadi multikolinearitas, bebas dari heteroskedastisitas, dan tidak terjadi autokorelasi.Dari hasil analisis diketahui bahwa secara simultan kecerdasan intelektual dan kecerdasan emosional berpengaruh terhadap tingkat pemahaman akuntansi, sedangkan secara parsial hanya kecerdasan intelektual yang berpengaruh signifikan terhadap tingkat pemahaman akuntansi.

\section{METODE PENELITIAN}

Jenis Penelitian

Penelitian ini merupakan penelitian hubungan kausal (causal effect). Penelitian ini dirancang untuk menguji pengaruh fakta dan fenomena serta mencari keterangan secara aktual yaitu penelitian yang bersifat menjelaskan mengenai pengaruh kecerdasan intelektual, kecerdasan emosional, kecerdasan spiritual, dan perilaku belajar terhadap pemahaman akuntansi bagi mahasiswa jurusan akuntansi pada Fakultas Ekonomi dan Bisnis Universitas Sam Ratulangi Manado.

\section{Populasi, Sampel, dan Teknik Pengambilan Sampel}

Populasi yang digunakan dalam penelitian ini adalah mahasiswa jurusan akuntansi pada Fakultas Ekonomi dan Bisnis Universitas Sam Ratulangi semester 8 dengan jumlah 274 mahasiswa. Dalam penelitian ini, yang menjadi sampel yang akan diteliti adalah mahasiswa jurusan akuntansi yang berada di semester 8 ketika penulisan ini sedang dilakukan, yaitu mahasiswa angkatan 2009. Adapun yang menjadi pertimbangan dari peneliti sebagai dasar pengambilan sampel adalah para mahasiswa dianggap telah menerima manfaat dari pembelajaran akuntansi. Penentuan jumlah sampel yang digunakan dalam penelitian ini diambil berdasarkan Dalil Batas Memusat (Central Limit Theorem), yang menyatakan bahwa distribusi rata-rata sampel dapat didekati dengan distribusi probabilitas normal untuk ukuran sampel yang besar (Supranto, 2001). Jumlah sampel yang besar maksudnya $n \geq 120$. Dalam penelitian ini, jumlah sampel yang dapat digunakan sejumlah 70 sampel, dan jumlah ini mendekati distribusi normal. 


\section{Instrumen Penelitian}

Penelitian ini adalah penelitian yang menggunakan instrumen penelitian kuesioner.

\section{Lokasi dan Waktu Penelitian}

Lokasi penelitian dari tesis ini adalah pada Fakultas Ekonomi dan Bisnis Universitas Sam Ratulangi Manado yang berlokasi di Manado. Sedangkan untuk waktu penelitian, diperkirakan untuk penyelesaian penelitian ini akan memerlukan waktu sekitar 1 bulan dengan bantuan dan arahan dari dosen pembimbing.

\section{Prosedur Pengumpulan Data}

Untuk mengumpulkan data, peneliti menyebarkan kuisioner kepada mahasiswa jurusan Akuntansi Fakultas Ekonomi dan Bisnis Universitas Sam Ratulangi Manado.Selain menggunakan kuisioner penulis juga mengumpulkan data-data yang relevan untuk penelitian ini.Perolehan informasi lain relevan dalam penelitian ini diperoleh dengan cara yaitu dengan membaca dan mempelajari sumber-sumber tertulis yang terkait dengan penelitian ini, baik berupa buku-buku, laporan hasil penelitian, tulisan ilmiah, jurnal, dokumen yang diperoleh dari tempat penelitian yang berkaitan dengan topik dan objek penelitian.

\section{Cara Pengolahan dan Analisis Data Metode Analisis Data}

Metode analisis yang dipakai dalam penelitian ini adalah analisis regresi linier berganda. Untuk pengolahan data pada penelitian ini menggunakan alat bantu program Statistical Product and Service Solutions (SPSS) versi 20. Berdasarkan hasil analisis tersebut nanti dapat diketahui variabel independen yang mana yang berpengaruh secara signifikan terhadap variabel dependennya.

\section{Teknik Analisis}

Teknik analisis yang digunakan adalah metode analisis kombinasi, yaitu analisis deskriptif dan analisis regresi berganda.

$$
\mathbf{Y}=\alpha+\boldsymbol{\beta}_{1} \mathbf{x}_{1}+\boldsymbol{\beta}_{2} \mathbf{x}_{2}+\boldsymbol{\beta}_{3} \mathbf{x}_{3}+\boldsymbol{\beta}_{4} \mathbf{x}_{4}+\varepsilon
$$

Adapun pengujian asumsi klasik yang dilakukan untuk menguji kelayakan persamaan yang digunakan dalam menjawab rumusan masalah dalam penelitian ini adalahuji kualitas data, uji normalitas, uji multikolinearitas, uji heteroskedastisitasdan uji autokorelasi, seperti dikutip oleh Sarjono dan Julianita (2011:53).

\section{HASIL PENELITIAN DAN PEMBAHASAN Gambaran Umum Objek Penelitian}

Penelitian ini difokuskan pada Fakultas Ekonomi dan Bisnis Universitas Sam Ratulangi Manado.Berdirinya Fakultas Ekonomi dan Bisnis UNSRAT tidak terlepas dari sejarah Universitas Sam Ratulangi, yang bermula dari dua Perguruan Tinggi.Pertama adalah Universitas Pinaesaan, didirikan di Tondano pada tanggal 1 Oktober 1954. Kedua adalah Universitas Permesta yang menyusul didirikan di Manado pada tanggal 23 September 1957. Pada tanggal 1 Agustus 1958, sesuai Surat Keputusan Penguasa Perang Daerah Sulawesi Utara Tengah No. 3/PENG/PMK/VII/ 1958 tertanggal 23 Juli 1958, maka keduanya dijadikan satu perguruan tinggi dengan nama Perguruan Tinggi Manado disingkat PTM dengan 4 fakultas, yaitu Fakultas Ekonomi, Fakultas Hukum, Fakultas Sastra, dan Fakultas Tatapraja. 
Pada bulan Oktober Tahun 1958 Perguruan Tinggi Manado (PTM) diganti nama menjadi Universitas Sulawesi Utara Tengah disingkat UNSUT. Pada tahun 1960 singkatan nama UNSUT diubah menjadi UNISUT, yang kemudian pada tahun 1961 disahkan sebagai Universitas Negeri melalui Keputusan Menteri PTIP No. 22 Thn. 1961 tanggal 4 Juli 1961, dengan nama Program Ekstensi. Pembukaan Program Ekstensi/Non Reguler didasarkan pada SK Direktur Jenderal Pendidikan Tinggi DEPDIKBUD No.413/Dikti Kep/1996, tanggal 6 Agustus 1996.

Era persaingan yang semakin ketat pada akhir abad 20 dan akan berlanjut di abad 21, dunia bisnis dan organisasi pemerintahan membutuhkan pemimpin dan manajer yang profesional agar bertahan dan unggul. Menyadari hal ini, Fakultas Ekonomi Unsrat membuka program pendidikan Strata Dua jalur profesi. Program pendidikan strata dua dimaksud adalah : 1). Program Magister Manajemen, dengan gelar MM, berdiri tahun 2000 berdasarkan SK. Dirjen Dikti Nomor 88/DIKTI/KEP/2000 tanggal 14 April 2000. 2). Program Magister Ekonomi Pembangunan, dengan gelar MEP, berdiri tahun 2003 berdasarkan SK. Dirjen Dikti Nomor : 918/D/T/2003 dari Magister Akuntansi Keuangan Daaerah yang akan dimulai pada tahun ajaran 2007/2008.

Pada tahun 2008, Fakultas Ekonomi Unsrat tetap menjadi Fakultas yang eksis bagi masyarakat Sulawesi Utara pada khususnya dan Indonesia dengan kualitas kinerja yang patut dibanggakan. Keberhasilan ini dapat dibuktikan dengan diraihnya Akreditas Nasional Perguruan Tinggi dari Badan Akreditasi Nasional Perguruan Tinggi (BAN-PT), dimana Program Studi Ilmu Ekonomi, Manajemen dan Akuntansi secara bersamaan mendapatkan Nilai Akreditasi A. Seiring keberhasilan tersebut, terdapat beberapa dosen yang diangkat menjadi tenaga Asesor pada BANPT tersebut.

Keberhasilan yang diraih ini belum menjadi titik balik bagi Fakultas Ekonomi Unsrat.Peningkatan kualitas pendidikan terus dipacu oleh seluruh civitas akademika melalui peningkatan kualitas pengajaran dengan menampilkan kurikulum-kurikulum berbasis kompetensi yang sesuai dengan kebutuhan pasar tenaga kerja serta peningkatan kualitas pendidikan bagi tenaga pengajar dan administrasi.Pada tahun ini terdapat beberapa dosen jenjang pendidikan S2 yang melanjutkan studi ke jenjang S3 baik diluar negeri dan didalam negeri.Juga terdapat beberapa dosen jenjang S1 yang melanjutkan studi ke jenjang S2 di dalam maupun diluar negeri.

\section{Hasil Penelitian \\ Deskripsi Data}

Data dalam penelitian ini dikumpulkan dengan cara menyebarkan kuisioner langsung kepada objek penelitian. Peneliti mengantarkan langsung kuisioner kepada responden untuk mengantisipasi terjadinya respond rate yang rendah pada saat pengembalian kuisioner. Sebanyak 100 kuisioner yang disebarkan, terkumpul sebanyak 90 kuisioner, hal ini disebabkan karena pada saat dikumpul, beberapa kuisioner tidak dikembalikan oleh responden.Jumlah sebanyak 90 kuisioner yang terkumpul, 20 kuisioner tidak dapat digunakan karena tidak diisi dengan lengkap, sehingga kuisioner yang dapat diolah sebanyak 70 kuisioner. 
Tabel 1. Rata-rata Tingkat Pemahaman Akuntansi Mahasiswa

\begin{tabular}{|c|c|c|c|}
\hline Item Variabel Y & Total & Rata-rata & Interpretasi \\
\hline Pengantar Akuntansi & 4835,1 & 69,07285714 & Baik \\
\hline Akuntansi Keuangan Menengah 1 & 4895,5 & 69,93571429 & Baik \\
\hline Akuntansi Keuangan Menengah 2 & 4827,0 & 68,95714286 & Baik \\
\hline Akuntansi Keuangan Lanjutan 1 & 5153,3 & 73,61857143 & Baik \\
\hline Akuntansi Keuangan Lanjutan 2 & 5085,3 & 72,64714286 & Baik \\
\hline Pemeriksaan Akuntansi 1 & 5051,0 & 72,15714286 & Baik \\
\hline Pemeriksaan Akuntansi 2 & 5083,0 & 72,61428571 & Baik \\
\hline Teori Akuntansi & 5418,0 & 77,4 & Sangat Baik \\
\hline
\end{tabular}

Dari tabel di atas, secara rata-rata kemampuan mahasiswa terhadap pemahaman akuntansi sudah baik.

Uji Validitas dan Reliabilitas Data

Tabel 2. Hasil Uji Validitas dan Reliabilitas Variabel Kecerdasan Intelektual

\begin{tabular}{lcccc}
\hline & $\left(\mathbf{X}_{\mathbf{1}}\right)$ & $\left(\mathbf{X}_{\mathbf{2}}\right)$ & $\left(\mathbf{X}_{\mathbf{3}}\right)$ & $\left(\mathbf{X}_{\mathbf{4}}\right)$ \\
\hline Corrected Item-Total Correlation P1 & 0,411 & 0,645 & 0.566 & 0,500 \\
Corrected Item-Total Correlation P2 & 0,554 & 0,537 & 0.642 & 0,623 \\
Corrected Item-Total Correlation P3 & 0,455 & 0,623 & 0.584 & 0,572 \\
Corrected Item-Total Correlation P4 & 0,622 & 0,523 & 0.715 & 0,372 \\
Corrected Item-Total Correlation P5 & 0,699 & 0,559 & 0.673 & 0,508 \\
Corrected Item-Total Correlation P6 & 0,573 & 0,398 & 0.646 & 0,669 \\
Corrected Item-Total Correlation P7 & 0,531 & 0,406 & 0.480 & 0,679 \\
Corrected Item-Total Correlation P8 & 0,606 & 0,545 & 0.484 & 0,637 \\
Corrected Item-Total Correlation P9 & 0,514 & 0,610 & 0.449 & 0,583 \\
Corrected Item-Total Correlation P10 & & 0,597 & & 0,311 \\
Corrected Item-Total Correlation P11 & & 0,593 & & 0,527 \\
Corrected Item-Total Correlation P12 & & 0,538 & & 0,651 \\
Corrected Item-Total Correlation P13 & & 0,555 & & 0,692 \\
Corrected Item-Total Correlation P14 & & & & 0,575 \\
Corrected Item-Total Correlation P15 & & & & 0,533 \\
Corrected Item-Total Correlation P16 & & & & 0,400 \\
Cronbach's Alpha & 0,750 & 0,748 & 0.756 & 0,749 \\
\hline
\end{tabular}

Dari tabel di atas dapat dilihat bahwa hasil uji validitas menunjukkan angka di atas 0,30 dan uji reliabilitas menunjukkan angka diatas 0,60 sehingga kuisioner tersebut valid dan reliabel.

Uji Asumsi Klasik

Uji Normalitas

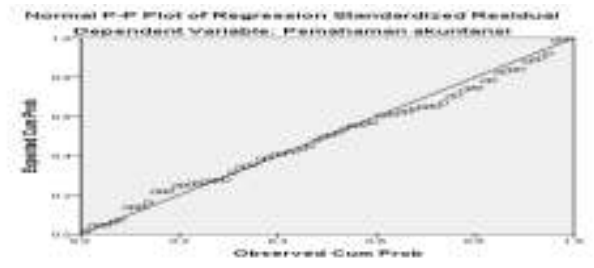

Gambar 1. Uji Normalitas 


\section{Uji Heteroskedastisitas}
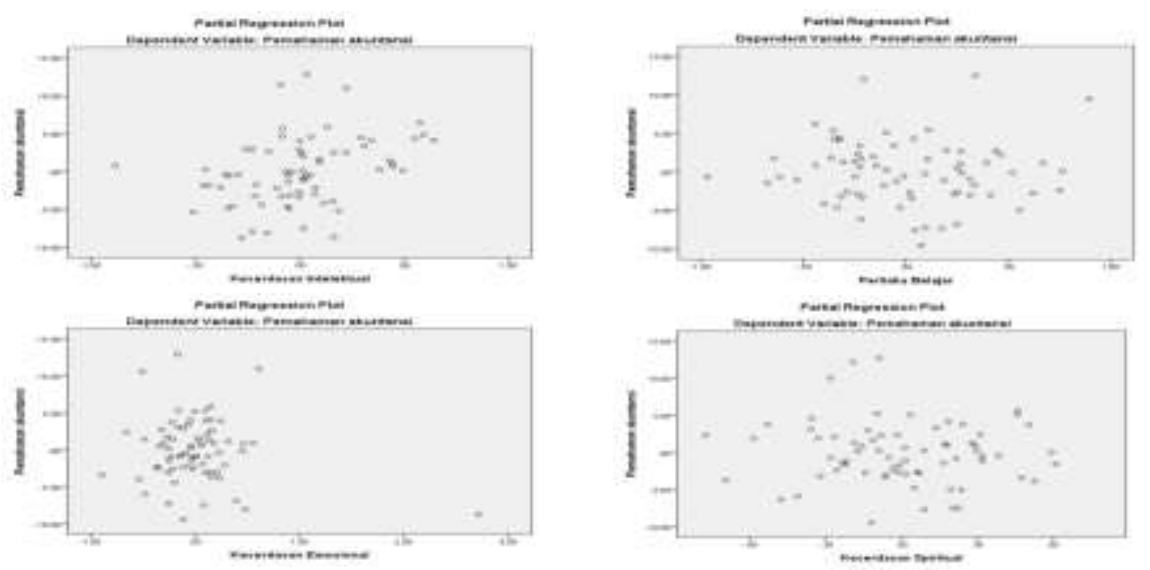

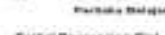

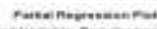

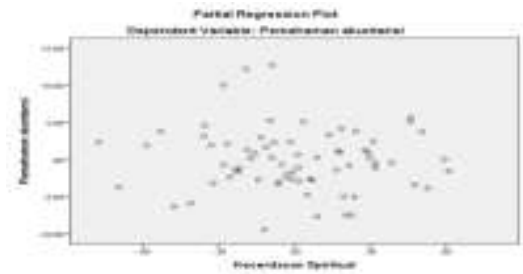

Gambar 2. Uji Heteroskedastisitas

\section{Uji Multikoleniaritas}

Tabel 3. Uji Multikolinearitas

\begin{tabular}{clcc}
\hline \multicolumn{1}{c}{ Model } & \multicolumn{2}{c}{ Collinearity Statistics } \\
\cline { 3 - 4 } & & & Tolerance \\
\hline 1 & (Constant) & & VIF \\
& Kecerdasan Intelektual & 0,457 & 2,187 \\
& Kecerdasan Emosional & 0,574 & 1,743 \\
& Kecerdasan Spiritual & 0,427 & 2,340 \\
& Perilaku Belajar & 0,675 & 1,481 \\
\hline
\end{tabular}

Output coefficients model dikatakan tidak terjadi gejala multikolinearitas karena VIF $<10$ dan tolerance $>0,1$.

Analisis Regresi Linear Berganda

Tabel 4. Koefisien Regresi

\begin{tabular}{clcc}
\hline \multicolumn{1}{c}{ Model } & \multicolumn{2}{c}{ Unstandardized Coefficients } \\
\cline { 3 - 4 } & & $\mathrm{B}$ & Std. Error \\
\hline 1 & (Constant) & 62,910 & 5,236 \\
& Kecerdasan Intelektual & 5,372 & 1,801 \\
& Kecerdasan Emosional & $-1,602$ & 1,197 \\
& Kecerdasan Spiritual & $-0,850$ & 1,718 \\
& Perilaku Belajar & $-0,358$ & 1,387 \\
\hline
\end{tabular}

Sumber: Hasil Olah Data SPSS, 2014

Hasil tersebut bila dimasukkan ke dalam persamaan regresi menjadi :

\section{$Y=62,910+5,372 x_{1}-1,602 x_{2}-0,850 x_{3}-0,358 x_{4}+e$}

Hasil regresi ini menunjukkan pengaruh beberapa variabel bebas terhadap variabel terikat yaitu pemahaman akuntansi. Nilai konstan sebesar 62,910 menunjukkan bahwa jika variabel kecerdasan intelektual $\left(\mathrm{x}_{1}\right)$, kecerdasan emosional $\left(\mathrm{x}_{2}\right)$, kecerdasan spiritual $\left(\mathrm{x}_{3}\right)$, dan perilaku belajar $\left(\mathrm{x}_{4}\right)$ dianggap konstan atau sama dengan nol (0) maka pemahaman akuntansi mahasiswa Fakultas Ekonomi dan Bisnis Universitas Sam Ratulangi Manado(Y) adalah sebesar 62,910 satuan score. 
Koefisien regresi $\mathrm{x}_{1}$ sebesar 5,372 mengartikan bahwa jika faktor kecerdasan intelektual $\left(\mathrm{x}_{1}\right)$ meningkat sebesar 1 satuan score dari kondisi sebelumnya maka pemahaman akuntansi mahasiswa Fakultas Ekonomi dan Bisnis Universitas Sam Ratulangi Manado(Y) akan meningkat sebesar 5,372 satuan score dari kondisi sebelumnya dengan asumsi variabel lain $\left(\mathrm{X}_{2}, \mathrm{X}_{3}, \mathrm{X}_{4}\right)$ yang diteliti tetap.

Koefisien regresi $\mathrm{x}_{2}$ sebesar -1,602 mengartikan bahwa jika faktor kecerdasan emosional $\left(\mathrm{x}_{2}\right)$ meningkat sebesar 1 satuan score dari kondisi sebelumnya maka pemahaman akuntansi mahasiswa Fakultas Ekonomi dan Bisnis Universitas Sam Ratulangi Manado(Y) akan berkurang sebesar -1,602 satuan score dari kondisi sebelumnya dengan asumsi variabel lain $\left(\mathrm{X}_{1}, \mathrm{X}_{3}, \mathrm{X}_{4}\right)$ yang diteliti tetap. Maksudnya adalah pemahaman akuntansi disini dilakukan dengan dengan penyelesaian kasus-kasus akuntansi. Penyelesaian dari kasus inilah yang dijadikan acuan kemampuan intelegensi mahasiswa. Kalau penyelesaian suatu kasus hanya mengandalkan emosi, atau hal-hal yang merupakan indikator kecerdasan emosional, maka tidak dapat terselesaikan, yang artinya bahwa mahasiswa mau tidak mau harus menyelesaikan kasus-kasus akuntansi tersebut dengan benar. Apabila mahasiswa tidak menyelesaikan kasus itu dengan benar maka mahasiswa itu tidak bisa lulus. Dalam pendidikan formal, kecerdasan emosional tidak bisa berdiri sendiri untuk mempengaruhi pemahaman mahasiswa, namun jika diterapkan untuk pendidikan informal besar kemungkinan mampu mengandalkan kecerdasan emosional secara terpisah. Contohnya adalah bermain musik, melukis, dan lain-lain, dimana pendidikan informal ini selalu mengutamakan perasaan, integritas, motivasi, dan lain-lain sesuai dengan indikator kecerdasan emosional tersebut.

Koefisien regresi $\mathrm{x}_{3}$ sebesar $-0,850$ mengartikan bahwa jika faktor kecerdasan spiritual $\left(\mathrm{x}_{3}\right)$ meningkat sebesar 1 satuan score dari kondisi sebelumnya maka pemahaman akuntansi mahasiswa Fakultas Ekonomi dan Bisnis Universitas Sam Ratulangi (Y) akan berkurang sebesar $-0,850$ satuan score dari kondisi sebelumnya dengan asumsi variabel lain $\left(\mathrm{X}_{1}, \mathrm{X}_{2}, \mathrm{X}_{4}\right)$ yang diteliti tetap. Kecerdasan spiritual yang diindikasikan dengan kemampuan menempatkan diri dalam lingkungan, kemampuan untuk segera mengerjakan pekerjaan atau tidak menunda pekerjaan yang menyebabkan kerugian, kemampuan untuk memotivasi diri dan lain-lain sebagainya kurang dimiliki oleh mahasiswa sehingga berpengaruh pada kemampuan mereka untuk menyesuaikan diri dalam proses pembelajaran efektif yang diharapkan bisa memahami akuntansi dengan baik. Kecerdasan spiritual akan lebih cocok diaplikasikan pada perilaku pengembangan karir dimana kecerdasan spiritual ini mempengaruhi tujuan seseorang dalam mencapai karirnya didunia kerja. Seseorang yang membawa makna spiritualitas dalam kerjanya akan merasakan hidup dan pekerjaannya lebih berarti. Hal ini mendorong dan memotivasi dirinya untuk lebih meningkatkan kinerja yang dimilikinya sehingga dalam karir ia dapat berkembang lebih maju.

Koefisien regresi $\mathrm{x}_{4}$ sebesar $-0,358$ mengartikan bahwa jika faktor perilaku belajar $\left(\mathrm{x}_{4}\right)$ meningkat sebesar 1 satuan score dari kondisi sebelumnya maka pemahaman akuntansi mahasiswa Fakultas Ekonomi Bisnis Universitas Sam Ratulangi Manado (Y) akan berkurang sebesar -0,358 satuan score dari kondisi sebelumnya dengan asumsi variabel lai $\left(\mathrm{X}_{1}, \mathrm{X}_{2}, \mathrm{X}_{3}\right)$ yang diteliti tetap. Mahasiswa walaupun memiliki perilaku belajar yang diindikasikan dengan beberapa indikator seperti memusatkan perhatian kepada dosen yang memberikan materi,selalu membuat catatan atau pertanyaan, atau yang selalu pergi ke perpustakaan, dan lain sebagainya belum tentu bisa menyerap atau memahami tugas yang diberikan oleh dosen. Masing-masing mahasiswa memiliki kemampuan yang berbeda dalam menerima dan mengolah informasi atau dalam hal ini ilmu yang di transfer oleh pengajar kepada mahasiswa, sehingga akan berpengaruh pada hasil akhir yang diharapkan yaitu pemahaman akuntansi yang lebih baik, yang diukur 
dengan nilai. Tanpa sumbangsih yang besar dari intelegensi, maka perilaku belajar tidak akan efektif dalam membantu memahami akuntansi.

Pengujian Hipotesis (Uji F)

Tabel 5. Analysis of Variance (ANOVA)

\begin{tabular}{|c|c|c|c|c|c|c|}
\hline Model & & Sum of Squares & $\mathrm{df}$ & Mean Square & $\mathrm{F}$ & Sig. \\
\hline \multirow{3}{*}{1} & Regression & 206,753 & 4 & 51,688 & 2,766 & $0,035^{\mathrm{b}}$ \\
\hline & Residual & 1214,665 & 65 & 18,687 & & \\
\hline & Total & 1421,418 & 69 & & & \\
\hline
\end{tabular}

Diketahui nilai $F_{\text {hitung }}=2,766$. Angka ini lebih besar dari $F_{\text {tabel }}=2,61$ pada tingkat $\alpha=0,05$. Dapat disimpulkan bahwa $\mathrm{H}_{0}$ ditolak dan $\mathrm{H}_{\mathrm{a}}$ diterima. Hal ini berarti, kecerdasan spiritual $\left(\mathrm{X}_{1}\right)$, kecerdasan emosional $\left(\mathrm{X}_{2}\right)$, kecerdasan spiritual $\left(\mathrm{X}_{3}\right)$, dan perilaku belajar $\left(\mathrm{X}_{4}\right)$ berpengaruh signifikan terhadap pemahaman akuntansi mahasiswa (Y).

Tabel 6. Uji t

\begin{tabular}{lcccccrr}
\hline \multirow{1}{*}{ Model } & \multicolumn{2}{c}{$\begin{array}{c}\text { Unstandardized } \\
\text { Coefficients }\end{array}$} & $\begin{array}{l}\text { Standardized } \\
\text { Coefficients }\end{array}$ & $\mathrm{t}$ & Sig. & \multicolumn{2}{c}{$\begin{array}{c}\text { 95\% Confidence } \\
\text { Interval for B }\end{array}$} \\
\cline { 2 - 8 } & $\mathrm{B}$ & $\begin{array}{c}\text { Std. } \\
\text { Error }\end{array}$ & Beta & & & $\begin{array}{r}\text { Lower } \\
\text { Bound }\end{array}$ & $\begin{array}{c}\text { Upper } \\
\text { Bound }\end{array}$ \\
\hline $\begin{array}{l}\text { Constant) } \\
\text { Kecerdasan }\end{array}$ & 62,910 & 5,236 & & 12,015 & 0,000 & 52,453 & 73,367 \\
$\begin{array}{l}\text { Intelektual } \\
\text { Kecerdasan }\end{array}$ & 5,372 & 1,801 & 0,506 & 2,983 & 0,004 & 1,775 & 8,968 \\
$\begin{array}{l}\text { Emosional } \\
\text { Kecerdasan }\end{array}$ & $-1,602$ & 1,197 & $-0,203$ & $-1,338$ & 0,186 & $-3,994$ & 0,789 \\
$\begin{array}{l}\text { Spiritual } \\
\text { Perilaku Belajar }\end{array}$ & $-0,850$ & 1,718 & $-0,087$ & $-0,495$ & 0,623 & $-4,281$ & 2,581 \\
\hline & $-0,358$ & 1,387 & $-0,036$ & $-0,258$ & 0,797 & $-3,128$ & 2,412 \\
\hline
\end{tabular}

Diketahui bahwa nilai $t_{\text {hitung }}$ untuk variabel kecerdasan intelektual $\left(\mathrm{x}_{1}\right)$ adalah 2,983 dengan tingkat kepercayaan 5\% pada derajat kebebasan $(\mathrm{N}-2)=70-2=68$, dapat diketahui nilai $t_{\text {tabel }}$ sebesar 2,000. Nilai $t_{\text {hitung }}>t_{\text {tabel }}$, dengan nilai signifikan $0,004<0,05$. Berdasarkan hasil output regresi diatas, diperoleh nilai $t_{\text {hitung }}>\mathrm{t}_{\text {tabel }}$, dengan demikian $\mathrm{H}_{0}$ ditolak dan $\mathrm{H}_{\mathrm{a}}$ diterima atau dengan kata lain variabel kecerdasan intelektual $\left(\mathrm{x}_{1}\right)$ berpengaruh signifikan dan searah/positif terhadap pemahaman akuntansi (Y). Variabel kecerdasan emosional $\left(\mathrm{x}_{2}\right)$, nilai $\mathrm{t}_{\text {hitung }}=-1,338$, dengan tingkat kepercayaan 5\% pada derajat kebebasan $(\mathrm{N}-2)=70-2=68$, dapat diketahui nilai $t_{\text {tabel }}$ sebesar 2,000. Nilai $t_{\text {hitung }}<t_{\text {tabel }}$ dengan nilai signifikan 0,186>0,05. Hal ini berarti $\mathrm{H}_{0}$ diterima dan $\mathrm{H}_{\mathrm{a}}$ ditolak atau dengan kata lainvariabel kecerdasan emosional tidak berpengaruh signifikan dan tidak searah/negatif terhadap pemahaman akuntansi mahasiswa. Variabel kecerdasan spiritual $\left(\mathrm{x}_{3}\right)$, nilai $\mathrm{t}_{\text {hitung }}=-0,495$, dengan tingkat kepercayaan $5 \%$ pada derajat kebebasan $(\mathrm{N}-2)=70-2=68$, dapat diketahui nilai $\mathrm{t}_{\text {tabel }}$ sebesar 2,000. Nilai $\mathrm{t}_{\text {hitung }}<\mathrm{t}_{\text {tabel }}$ dengan nilai signifikan 0,623>0,05. Hal ini berarti $\mathrm{H}_{0}$ diterima dan $\mathrm{H}_{\mathrm{a}}$ ditolak atau dengan kata lainvariabel kecerdasan spiritual tidak berpengaruh signifikan dan tidak searah/negatif terhadap pemahaman akuntansi mahasiswa. Variabel perilaku belajar $\left(\mathrm{x}_{3}\right)$, nilai $\mathrm{t}_{\text {hitung }}=-0,258$, dengan tingkat kepercayaan $5 \%$ pada derajat kebebasan $(\mathrm{N}-2)=70-2=68$, dapat diketahui nilai $\mathrm{t}_{\text {tabel }}$ sebesar 2,000. Nilai $t_{\text {hitung }}<\mathrm{t}_{\text {tabel }}$ dengan nilai signifikan $0,797>0,05$. Hal ini berarti $\mathrm{H}_{0}$ diterima dan $\mathrm{H}_{\mathrm{a}}$ ditolak atau dengan kata lainvariabel perilaku belajar tidak berpengaruh signifikan dan tidak searah/negatif terhadap pemahaman akuntansi mahasiswa. 
Tabel 7. Koefisien Korelasi

\begin{tabular}{llrrrrr}
\hline & & $\begin{array}{c}\text { Pemahaman } \\
\text { akuntansi }\end{array}$ & $\begin{array}{r}\text { Kecerdasan } \\
\text { Intelektual }\end{array}$ & $\begin{array}{r}\text { Kecerdasan } \\
\text { Emosional }\end{array}$ & $\begin{array}{c}\text { Kecerdasan } \\
\text { Spiritual }\end{array}$ & $\begin{array}{c}\text { Perilaku } \\
\text { Belajar }\end{array}$ \\
\hline Pearson & Pemahaman akuntansi & 1,000 & 0,317 & 0,005 & 0,141 & 0,045 \\
Correlation & Kecerdasan Intelektual & 0,317 & 1,000 & 0,546 & 0,715 & 0,450 \\
& Kecerdasan Emosional & 0,005 & 0,546 & 1,000 & 0,576 & 0,515 \\
& Kecerdasan Spiritual & 0,141 & 0,715 & 0,576 & 1,000 & 0,485 \\
& Perilaku Belajar & 0,045 & 0,450 & 0,515 & 0,485 & 1,000 \\
Sig.(1-tailed) & Pemahaman akuntansi & & 0,004 & 0,484 & 0,123 & 0,355 \\
& Kecerdasan Intelektual & 0,004 &. & 0,000 & 0,000 & 0,000 \\
& Kecerdasan Emosional & 0,484 & 0,000 & & 0,000 & 0,000 \\
& Kecerdasan Spiritual & 0,123 & 0,000 & 0,000 &. & 0,000 \\
& Perilaku Belajar & 0,355 & 0,000 & 0,000 & 0,000 &. \\
& Pemahaman akuntansi & 70 & 70 & 70 & 70 & 70 \\
& Kecerdasan Intelektual & 70 & 70 & 70 & 70 & 70 \\
& Kecerdasan Emosional & 70 & 70 & 70 & 70 & 70 \\
& Kecerdasan Spiritual & 70 & 70 & 70 & 70 & 70 \\
& Perilaku Belajar & 70 & 70 & 70 & 70 & 70 \\
\hline
\end{tabular}

Berdasarkan hasil olah data maka diketahui bahwa variabel kecerdasan intelektual $\left(\mathrm{X}_{1}\right)$ mempunyai korelasi yang cukup dan positif terhadap variabel pemahaman akuntansi mahasiswa (Y).Hal ini ditunjukkan dengan nilai koefisien korelasi sebesar 0,317.Variabel kecerdasan emosional $\left(\mathrm{X}_{2}\right)$ mempunyai nilai koefisien korelasi sebesar 0,005.Hal ini berarti variabel kecerdasan emosional memiliki korelasi yang sangat lemah tapi masih positif terhadap variabel pemahaman akuntansi $(Y)$, sedangkan untuk variabel kecerdasan spiritual $\left(\mathrm{X}_{3}\right)$ memiliki korelasi sangat lemah tapi masih positif terhadap variabel pemahaman akuntansi (Y).Hal ini ditunjukkan dengan nilai koefisien korelasi sebesar 0,141.Variabel perilaku belajar $\left(\mathrm{X}_{4}\right)$ juga memiliki korelasi yang sangat lemah dan positif terhadap variabel pemahaman akuntansi (Y).Hal ini ditunjukkan dengan nilai koefisien korelasi sebesar 0,045.

Koefisien Determinasi $\left(\mathbf{R}^{2}\right)$

Tabel 8. Koefisien Determinasi

\begin{tabular}{ccccc}
\hline Model & $\mathrm{R}$ & $\mathrm{R}$ Square & Adjusted R Square & $\begin{array}{c}\text { Std. Error of the } \\
\text { Estimate }\end{array}$ \\
\hline 1 & $0,381^{\mathrm{a}}$ & 0,145 & 0,093 & 4,32286 \\
\hline
\end{tabular}

Berdasarkan hasil olah data SPSS untuk model Summary, maka dapat diketahui bahwa nilai dari koefisien determinasi atau R Square adalah sebesar 0,145 atau 14,5\%. Angka tersebut berarti pemahaman akuntansi mahasiswa Fakultas Ekonomi dan Bisnis Universitas Sam Ratulangi dapat dijelaskan oleh variabel kecerdasan intelektual, kecerdasan emosional, kecerdasan spiritual, dan perilaku belajar. Sedangkan sisanya $(100 \%-14,5 \%=85,5 \%)$ dijelaskan oleh variabel lain yang tidak dimasukkan dalam model penelitian ini.

\section{Pembahasan}

\section{Kecerdasan intelektual berpengaruh terhadap pemahaman akuntansi mahasiswa}

Secara teori yang disampaikan oleh Gardner (Uno, 2010), yang menjelaskan kecerdasan atau intelegensi sebagai kemampuan untuk menyelesaikan masalah yang terjadi dalam kehidupan manusia.Dengan demikian secara teori benar adanya bahwa kecerdasan intelektual ini berpengaruh terhadap pemahaman akuntansi. 


\section{Kecerdasan emosional berpengaruh terhadap pemahaman akuntansi mahasiswa}

Kesadaran yang besar dari mahasiswa itu sendiri untuk lebih memprioritaskan tujuan utama yaitu belajar agar bisa mendapat nilai yang bagus, dan juga peran serta dosen sangat diperlukan misalnya tidak memperbolehkan mahasiswa untuk menggunakan handphone selama perkuliahan berlangsung, atau mungkin bisa lebih kreatif dalam membawakan materi kuliah agar mahasiswa bisa menerima ilmu tersebut dengan baik.

\section{Kecerdasan spiritual berpengaruh terhadap pemahaman akuntansi mahasiswa}

Kecerdasan spiritual muncul karena adanya perdebatan antara kecerdasan intelektual dan kecerdasan emosional, dimana kecerdasan spiritual ini berperan sebagai landasan untuk memfungsikan kecerdasan intelektual dan kecerdasan emosional secara efektif (Agustian,2001) dalam Trihandini (2005).Hal ini berarti bahwa kecerdasan spiritual tidak bisa berdiri sendiri untuk mempengaruhi pemahaman akuntansi, melainkan harus difungsikan bersama dengan kecerdasan intelektual dan kecerdasan emosional.

\section{Perilaku belajar berpengaruh terhadap pemahaman akuntansi}

Walaupun dari hasil penelitian dikatakan bahwa perilaku belajar secara signifikan tidak berpengaruh terhadap pemahaman akuntansi, pengaruhnya tetap ada walaupun tidak begitu terasa tanpa didukung oleh kecerdasan intelektual, kecerdasan emosional, kecerdasan spiritual, motivasi, dan faktor lain yang tidak disebutkan dalam model penelitian ini.

\section{PENUTUP}

\section{Kesimpulan}

Berdasarkan hasil penelitian dan pembahasan maka dapat disimpulkan beberapa kesimpulan sebagai berikut.

1. Kecerdasan intelektual berpengaruh signifikan dan searah/positif terhadap pemahaman akuntansi mahasiswa Fakultas Ekonomi dan Bisnis Universitas Sam Ratulangi Manado. Untuk bisa memahami akuntansi diperlukan peran kecerdasan intelektual, yaitu kecerdasan yang berhubungan dengan penalaran terhadap kasus-kasus akuntansi sehingga bisa memperoleh nilai yang baik, yang dijadikan sebagai tolak ukur dari pemahaman akuntansi.

2. Kecerdasan emosional tidak berpengaruh secara signifikan dan tidak searah/negative terhadap pemahaman akuntansi mahasiswa Fakultas Ekonomi dan Bisnis Universitas Sam Ratulangi Manado. Hal ini bisa dimaklumi karena mahasiswa masih belum bisa memanfaatkan emosi mereka dalam mengoptimalkan potensi intektual yang sebenarnya mereka miliki. Banyak dari mahasiswa yang tidak memprioritaskan tujuan utama mereka yaitu belajar, mereka lebih senang untuk bermain game atau mengobrol ketika perkuliahan berlangsung. Adanya dosen favorit juga turut berperan dalam mempengaruhi kemauan mereka dalam memperhatikan materi dengan cermat dalam kelas.

3. Kecerdasan spiritual tidak berpengaruh secara signifikan/tidak searah terhadap pemahaman akuntansi. Hal ini bisa dimaklumi karena ketika mahasiswa dihadapkan pada penderitaan atau masalah, mahasiswa dengan kecerdasan spiritual yang tinggi akan bisa memanfaatkan atau melihat penderitaan dengan positif, menjadikan hal tersebut sebagai penyemangat untuk terus terpacu dalam belajar, bukannya dijadikan sebagai kendala yang menjatuhkan semangat, sehingga mahasiswa tersebut bisa tetap focus dan memotivasi diri untuk belajar memahami akuntansi.

4. Perilaku belajar tidak berpengaruh secara signifikan/negative terhadap pemahaman akuntansi mahasiswa. Hal ini bisa dimaklumi karena mahasiswa tidak belajar secara teratur, baik dan disiplin. Hal lain yang bisa dipahami adalah karena setiap mahasiswa 
memiliki kendala tersendiri dalam menyerap materi yang diberikan sehingga berpengaruh pada hasil ujian dalam bentuk nilai yang dijadikan sebagai ukuran pemahaman akuntansi.

\section{Saran} ini.

1. Penyelenggara program studi Akuntansi diharapkan untuk selalu melakukan penyesuaian dan pengembangan kurikulum yang sejalan dengan perkembangan ekonomi dan bisnis sehingga dapat meningkatkan kualitas pendidikan dan menghasilkan lulusan yang berkualitas serta berkompeten.

2. Mahasiswa akuntansi diharapkan meningkatkan perilakubelajar yang baik dan tetap memotivasi diri untuk mau belajar dengan giat agar dapat meningkatkan pemahaman akuntansi agar ketika lulus dari perkuliahan bisa diandalkan dan siap pakai dilapangan pekerjaan dengan keahlian dibidang akuntansi.

3. Penelitian selanjutnya diharapkan dapat memperluas populasi dan jumlah sampel, sehingga diharapkan dapat diperoleh hasil penelitian yang lebih baik. Penelitian yang akan datang juga dapat melibatkan sampel mahasiswa angkatan yang lainnya.

4. Penambahan variabel lainnya untuk penelitian selanjutnya yang mungkin dapat mempengaruhi pemahaman akuntansi seperti motivasi, stress kuliah, atau bisa juga beberapa dari faktor internal yang mempengaruhi proses belajar itu sendiri seperti bakat dan minat, dan lain sebagainya.

\section{DAFTAR PUSTAKA}

Agustian, Ary Ginanjar. 2005. ESQ Power. Jakarta: Penerbit Arga.

Alma, Buchari. H. 2004. Metode \&Teknik Menyusun Tesis. Penerbit Alfabeta. Bandung

Durgut, et al. 2013. The Impact of Intelligence Quotient on the Achievement of Accounting Subject. International Journal dan Bussines and Social Science, Vol 4.No.13, Turkey.

Dwijayanti, Arie. 2009. Pengaruh Kecerdasan Emosional, Kecerdasan Intelektual, Kecerdasan Spiritual, dan Kecerdasan Sosial terhadap Pemahaman Akuntansi, Universitas Pembangunan Nasional "Veteran", Jakarta.

Harahap, Sofyan Syafri, 2007. Teori Akuntansi. Raja Grafindo Persada, Jakarta. http://finance.detik.com/read/2012/07/05/122510/1958279/4/kasihan-ada-493000-sarjanamenganggur-di-indonesia

http://pena.gunadarma.ac.id/global-competitiveness-report-2012-2013-daya-saing-indonesiamenurun/

Napitupulu, Ilham. 2009. Pengaruh Kecerdasan Intelektual dan Kecerdasan Emosional Terhadap Tingkat Pemahaman Pelajaran Akuntansi Dengan Minat Sebagai Variabel Moderating pada SMK Bisnis dan Manajemen Kota Sibolga Kelas XII Jurusan Akuntansi, Sekolah Pascasarjana, USU, Medan.

Poerwati, Tjahjaning. 2010. Pengaruh Perilaku Belajar dan Motivasi terhadap Prestasi Akademik Mahasiswa Akuntansi di Universitas STIKUBANK, Semarang.

Praja, Juhaya S, dan Effendi, Usman. 2012. Pengantar Psikologi. Penerbit Angkasa: Bandung. Priyatno, Dwi. 2008. Mandiri Belajar SPSS.Mediakom: Yogyakarta. 
Rachmi, Filia. 2010. Pengaruh Kecerdasan Emosional, Kecerdasan Spiritual, dan Perilaku Belajar terhadap Pemahaman Akuntansi, Fakultas Ekonomi, Universitas Diponegoro, Semarang.

Risyo, Melandy RM, dan Nurna, Aziza, 2006. Simposium Nasional Akuntansi-IX Padang Pengaruh Kecerdasan Emosional Terhadap Tingkat Pemahaman Akuntansi Kepercayaan Diri Sebagai Variabel Pemoderasi.

Sari, Yora K, 2007.Pengaruh Pengendalian Diri dan Perilaku Belajar terhadap Tingkat Pemahaman Akuntansi, Padang.

Sarjono Haryadi, dan Julianita Winda. 2011. SPSS vs LISREL.Penerbit Salemba Empat: Jakarta.

Suartana, I Wayan.(2010). Akuntansi Keperilakuan.Penerbit ANDI, Yogyakarta.

Subini, et al. 2012.Psikologi Pembelajaran. Mentari Pustaka, Jakarta.

Sugiyono. 2013. Metode Penelitia nPendidikan. Penerbit Alfabeta: Bandung.

Supranto, J. 2001. Statistik (Teoridan Aplikasi). Erlangga.

Syukriy, A.dan Hanifah, 2000.Pengaruh Perilaku Belajar Terhadap Prestasi Akademik Mahasiswa Akuntansi. Media Riset Akuntansi, Auditing ,dan Informasi, Vol 1, Nomor 3, Desember 2001.

Trihandini, Fabiola.,2005. Analisis Pengaruh Kecerdasan Intelektual, Kecerdasan Emosi, dan Kecerdasan Spiritual terhadap Kinerja Karyawan, Program Pascasarjana, Universitas Diponegoro, Semarang.

Uno, Hamzah B, 2010. Orientasi Baru Dalam Psikologi Pembelajaran, Bumi Aksara, Jakarta.

Widagdo, Nunie Retna, 2010. Psiko diagnostik II. Pengembangan Bahan Ajar Universitas Mercu Buana, Jakarta. 